\title{
The pharmacology of inhaled nitric oxide
}

\author{
A D Edwards
}

In 1980 Furchgott and Zawadski reported that endothelial cells stimulated by acetylcholine produced a vasodilator substance which relaxed vascular smooth muscle. ${ }^{1}$ The identity of this endothelium derived relaxing factor (EDRF) remained elusive until 1987 when Palmer and colleagues showed that the effects of nitric oxide (NO) accounted for the known biological actions of EDRF, ${ }^{2}$ and that endothelial cells synthesised NO from L-arginine and oxygen. ${ }^{3}$

The demonstration that analogues of L-arginine, such as $\mathrm{N}^{\mathrm{G}}$-monomethyl-L-arginine (LNMMA) and $\mathrm{N}^{\mathrm{G}}$-nitro-L-arginine methyl ester (L-NAME), prevented the production of NO by cells provided an experimental tool for examining the widespread biological roles of NO. ${ }^{4}$ Administration of L-NMMA or L-NAME to animals blocked the vasodilator action of acetylcholine, caused a persistent rise in blood pressure, and reduced the blood volume of organs such as the brain, demonstrating both that NO release contributes to a constant vasodilator tone, and that further release can be initiated by appropriate stimuli. ${ }^{56}$ Conversely, administration of drugs which produced NO, such as the nitrate vasodilators, produced a fall in blood pressure. ${ }^{5}$

Several isoforms of the enzyme nitric oxide synthase (NOS) have been characterised both constitutive and inducible. Constitutive enzymes were found in many tissues, including endothelium and brain. ${ }^{5} 7$ An inducible form of the enzyme, which was expressed after cytokine stimulation and during sepsis, was found in macrophages. $58 \mathrm{NO}$ is now known to be a multifunctional biological mediator with diverse roles in the cardiovascular, neurological, immunological and many other systems. ${ }^{9}$

Agonists and antagonists of NO have many potential medicinal roles, but among the first to be examined in detail is the use of inhaled NO as a specific pulmonary vasodilator. Information about this novel drug is accumulating, although there remain extensive gaps in our knowledge of its pharmacology and toxicology.

\section{Chemistry}

Nitric oxide (nitrogen monoxide) is a volatile gas which is the second (nitrogen oxidation state +2 ) in the sequence of oxy-compounds of nitrogen that includes $\mathrm{NO}^{-}$(oxidation state
+1 ) and $\mathrm{NO}^{+}$(oxidation state +3 ). The characteristic chemistry of $\mathrm{NO}$ is largely due to the arrangement of the electrons in the valence shell. Nitrogen and oxygen combine to form four bonding and four antibonding orbitals which are filled by 11 electrons, giving the molecule eight bonding and three antibonding electrons, a bond order of $2 \cdot 5$, and a bond length intermediate between double and triple bonding $(1 \cdot 150 \mathrm{~A}) .^{10}$

The single unpaired electron in the $2^{\star} \mathrm{p} \pi$ molecular orbital defines the molecule as a free radical ( the presence of this unpaired electron is sometimes emphasised by writing the formula as $\cdot \mathrm{NO}^{10}$ ). However, NO does not exhibit the high reactivity characteristic of most free radicals and shows little tendency to dimerise. Nevertheless, in the presence of superoxide radical reactions occur which lead to highly reactive species being formed ${ }^{11}$; these are described further below.

NO is thermodynamically unstable $\left(\Delta \mathrm{G}_{\text {formation }}^{\mathrm{O}}=86.32 \mathrm{~kJ}\right)$, but decomposition is kinetically hindered and the gas and can be stored indefinitely at room temperature and 1 atmosphere pressure. At increased pressure, disproportionation of $\mathrm{NO}$ to $\mathrm{N}_{2} \mathrm{O}$ and $\mathrm{NO}_{2}$ can occur. This reaction obeys third order kinetics and at $30^{\circ} \mathrm{C}$ and 200 atmospheres pressure, some NO initially present may be converted into $\mathrm{N}_{2} \mathrm{O}$ and $\mathrm{NO}_{2}$. This needs to be considered when $\mathrm{NO}$ is stored in pressurised cylinders for clinical use. ${ }^{10}$

In aqueous solutions NO exhibits solubility and diffusibility similar to other diatomic gases. It does not interact with water, and this property is probably relevant to its pharmacological and biological effects. The diffusion coefficient of $\mathrm{NO}$ in tissue and the lipid membrane permeability have not yet been formally quantified. ${ }^{11} \mathrm{NO}$ is not affected by light.

The unpaired electron is antibonding and easily detached to allow $\mathrm{NO}^{+}$to be formed. Although the lifetime of $\mathrm{NO}^{+}$in aqueous media is very short, it has been suggested that the presence in tissue of alternative redox forms of NO might lead to potent changes in biological effects. ${ }^{12}$

\section{Metabolism}

Both the effects and metabolism of inhaled NO take place in the lung, where several of the chemical reactions of $\mathrm{NO}$ are relevant: 
REACTIONS WITH HAEM CONTAINING

METALLOPROTEINS

Reactions with haem containing proteins are rapid. The association rate constant with $\mathrm{Fe}$ (II) in haemoglobin is about 300 times greater than for oxygen. This reaction leads to the formation of $\mathrm{Fe}$ (III) haemoglobin (methaemoglobin) and $\mathrm{NO}_{2}{ }^{-}$. $\mathrm{NO}$ also binds to $\mathrm{Fe}$ (III) complexes and $\mathrm{Fe}$ (III)NO undergoes a transfer reaction to form $\mathrm{Fe}(\mathrm{II}) \mathrm{NO}^{+}$. $\mathrm{NO}^{+}$can be oxidised to $\mathrm{NO}_{2}{ }^{-}$and $\mathrm{NO}_{3}{ }^{-}$so that $\mathrm{NO}$ is cleared rapidly from the blood. ${ }^{11}$ The reaction of NO with haem groups is thought to be the predominant interaction in biological systems, and to account both for its activity in smooth muscle cells and its rapid inactivation in blood. ${ }^{11}$

\section{FREE RADICAL REACTIONS}

NO reacts with the superoxide anion $\left(\mathrm{O}_{2}{ }^{-}\right)$, leading to the production of peroxynitrite $\left(\mathrm{OONO}^{-}\right)$. At physiological $\mathrm{pH}, \mathrm{OONO}^{-}$has a half life of 1.9 seconds, being protonated to form $\mathrm{ONOOH}$ which undergoes spontaneous homolysis to form the highly reactive hydroxyl radical $\left(\cdot \mathrm{OH}^{-}\right) \cdot{ }^{13}$ The hydroxyl radical is highly damaging to lipid membranes, and consequently the potential for NO administration to induce tissue injury has led to a great deal of interest in this reaction, and to the role of NO as a cell toxin. ${ }^{14}$

\section{AUTOXIDATION}

The reaction between $\mathrm{NO}$ and $\mathrm{O}_{2}$ to form $\mathrm{NO}_{2}$ is rapid at high concentrations of NO, but slow at the concentrations used in trials of inhaled NO treatment. In air, for low concentrations of $\mathrm{NO}$ the half life of $\mathrm{NO}$ and the rate of $\mathrm{NO}_{2}$ formation depend on the initial concentration; the half life may vary between one and 500 seconds. ${ }^{10}$ It is reported that at NO concentrations of 40 parts per million (ppm) or less, combination of $\mathrm{NO}$ with pure oxygen requires 2.56 minutes to yield $5 \mathrm{ppm} \mathrm{NO}$, although at $120 \mathrm{ppm}$ NO this time falls to 0.26 minutes. ${ }^{15}$ $\mathrm{NO}_{2}$ is an environmental toxin which can cause pulmonary oedema, haemorrhage, and bronchiolitis obliterans, ${ }^{16}$ and inhalation of $\mathrm{NO}_{2}$ at concentrations as low as $2 \mathrm{ppm}$ caused lung epithelial damage. A considerable body of published data exists on the effects of inhaled $\mathrm{NO}_{2}$, suggesting that $5 \mathrm{ppm}$ is a maximum safe dose. ${ }^{17}$ Clinical administration systems should minimise the period of $\mathrm{NO}$ and $\mathrm{O}_{2}$ mixing to prevent extracorporeal $\mathrm{NO}_{2}$ formation. Within tissue NO has a higher affinity for haemoglobin than oxygen, minimising autoxidation in blood.

\section{FORMATION OF NITROSOTHIOL COMPOUNDS}

NO undergoes nitrosation reactions, and in biological systems the formation of nitrosothiols seems to be favoured. The reaction of NO with RSH to form RSNO is rapid but the resulting nitrosothiol is unstable and the reaction is reversible. ${ }^{10}$ The presence of nitrosothiols in human plasma supports the suggestion that nitrosothiols may represent a 'stabilised' form of NO in biological tissue. ${ }^{18}$

\section{Pharmacokinetics}

Inhaled NO is taken up into the precapillary airspaces and alveoli at a rate many times faster than inhaled oxygen, and the diffusing capacity of the lung is 4.5 times higher for NO than for carbon monoxide. ${ }^{19}$ The anatomical proximity of the airspaces to muscular arterioles allows NO to diffuse into contact with the abluminal surface of these vessels. ${ }^{19}$

Because of rapid removal of NO by reaction with haemoglobin, the effects of NO inhalation are generally considered to be localised to lung tissue with an effective half life of 2-6 seconds. ${ }^{20}$ The half life of potential 'stabilised' forms of NO (S-nitrosothiols) is longer, and nitrosothiols may prolong the actions of $\mathrm{NO}$ in tissue. ${ }^{921}$ The metabolites of NO are cleared from the body by the kidneys within five to eight hours ${ }^{9}$ and concentrations of methaemoglobin rarely rise above $1-2 \%$ during NO treatment. ${ }^{22} 23$

\section{Pharmacology}

MECHANISMS OF ACTION

Inhaled NO diffuses from alveoli into cells ${ }^{16}$ where it binds to the prosthetic haem group of the soluble guanylate cyclase enzyme (GTP pyrophosphatelyase (cyclising); EC 4.6.1.2). ${ }^{24}$ NO binding leads to a conformational change similar the effect of oxygen, ${ }^{25}$ and causes a rise in intracellular cyclic guanylate monophosphate (cGMP), which in turn leads to muscular relaxation and vasodilation (figure). An independent effect of NO on calcium dependent potassium channels has also been described, ${ }^{26}$ and preliminary evidence suggests a direct activation of G-proteins. ${ }^{27} \mathrm{NO}$ may also stimulate prostanoid synthesis by reacting with the haem in prostaglandin $\mathrm{H}$ synthase. ${ }^{28}$

It remains controversial whether these effects are entirely due to the action of NO itself, or also to nitrosothiol metabolites such

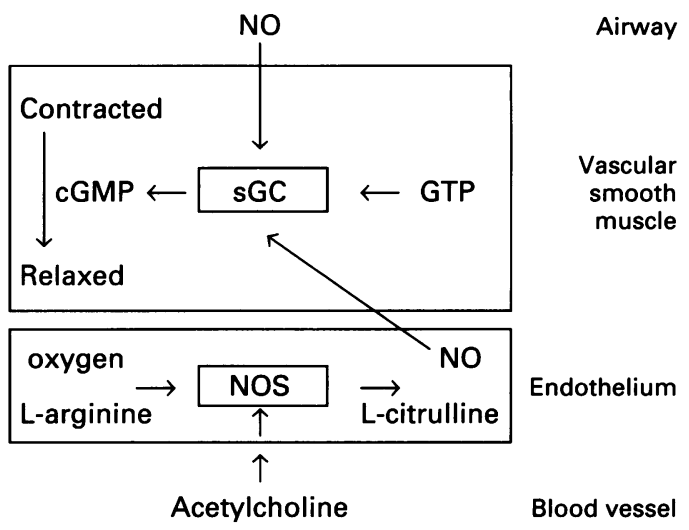

Physiological and pharmacological actions of NO on vascular smooth muscle. Physiological stimuli, such as acetylcholine, activate constitutive nitric oxide synthase (NOS) in endothelial cells, which converts L-arginine and oxygen to L-citrulline and nitric oxide (NO). NO diffuses to smooth muscle cells and activates soluble guanylate cyclase (cGC) which converts GTP to cyclic-GMP, leading to muscular relaxation. Pharmacological administration of NO into the airways acts directly on guanylate cyclase. 
as S-nitrosocysteine. ${ }^{29} 30$ Inhaled NO may also have some distant effects mediated by nitrosothiols, as prolongation of the bleeding time has been reported in healthy adult volunteers who inhaled NO, ${ }^{31}$ and rats treated with inhaled NO developed prolonged brainstem evoked responses and impaired learning. ${ }^{32}$ However, such actions are probably minor.

\section{PHARMACOLOGICAL EFFECTS}

NO mediated relaxation of vascular smooth muscle leads to vasodilation ${ }^{5}$ and bronchodilation. ${ }^{1633}$ In newborn lambs and piglets it has no effect on the normal pulmonary vasculature, but reverses the vascoconstriction induced by hypoxia or vasoconstrictor prostanoids, and this effect is not abolished by concomitant acidaemia. ${ }^{34-36}$ Vasodilation can occur in the presence of endothelial damage which abolishes the vasodilatory effect of acetylcholine, ${ }^{37}$ and it is more effective than inhalation of prostaglandin $\mathrm{I}_{2} \cdot{ }^{38}$ In piglets inhaled NO reduces the vasoconstriction associated with bacterial sepsis. ${ }^{39}$

Because inhaled NO is delivered to ventilated lung segments, its vasodilatory effect improves ventilation:perfusion matching and oxygen transport so that improved oxygenation has been observed even without a fall in pulmonary artery pressure. ${ }^{40}$ This effect may be potentiated by the effects of NO on bronchial smooth muscle: inhaled NO reduces the bronchconstrictor effect of inhaled metacholine in guinea pigs and rabbits, although at inhaled concentrations of $80-300 \mathrm{ppm}$, higher than those required for vasodilation $(5-80$ ppm). ${ }^{16}$

Other actions of NO may be relevant during inhalation treatment: leakage of albumin into the alveolar space after pulmonary injury is reduced ${ }^{41}$; adhesion and aggregation of platelets and leucocytes are inhibited ${ }^{42}$; the effects of endothelin-1 and other vasoactive agents on pulmonary vessels may be antagonised. ${ }^{43} 44$ NO has a negative feedback effect on NO synthesis, raising concern that inhaled NO may depress endogenous pulmonary vasodilatation. ${ }^{45-47}$

NO has many further biological effects, including inhibition of platelet aggregation ${ }^{5}$ and a negative inotropic effect. ${ }^{48}$ Cytokine activated macrophages use NO to kill tumour cells, fungi, bacteria, viruses and helminths. ${ }^{8}$ NO can disrupt enzymes in both the Krebs cycle (aconitase), mitochondrial complex I (reduced nicotinamide-adenine dinucleotide phosphate-NADH dehydrogenase), and mitochondrial complex II (succinate-NADH dehydrogenase), as well as the rate limiting enzyme in DNA synthesis (ribonucleosidediphospate reductase). ${ }^{49}$ NO modulates gene transcription and post-transcription processing $^{50}$ and may play an important part in inflammation: it enhances the effects of cyclooxygenase I and II and stimulates the production of some proinflammatory eiconosoids. ${ }^{28}$ Immune complex induced injury in rat lung ${ }^{51}$ and inflammatory damage to other tissues are reduced by NO inhibitors. ${ }^{52} 53$ NO acts as a neurotransmitter in the central and peripheral nervous systems, notably in non-adrenergic, non-cholinergic fibres, which are prominent in lung. ${ }^{16} \mathrm{NO}$ has been implicated as a mediator of cell death in the nervous system. ${ }^{54}$

\section{Toxicology}

Inhalational NO is not a licensed drug, and full toxicology data are unavailable. Although the many functions of $\mathrm{NO}$ in the body mean that modulation of NO metabolism or effects could have far reaching results, it is generally assumed that systemic toxicity is low because of rapid inactivation of NO on contact with blood.

Studies in rats have shown that inhalation of up to $1500 \mathrm{ppm}$ NO for 15 minutes caused no demonstrable lung injury. ${ }^{55}$ Overdose of 20000 ppm caused acute pulmonary oedema and methaemoglobinaemia. ${ }^{16}$ Unfortunately, such studies are of limited relevance to clinical uses of the drug.

Reports of adverse effects in clinical studies have been rare: paradoxical hypoxia during NO inhalation in one newborn infant has been reported, and it was suggested (without supporting evidence) that this was related to maternal indomethacin treatment. ${ }^{56}$ The increase in bleeding time demonstrated in adult volunteers does not seem to be a significant problem in clinical practice. ${ }^{31}$

Nevertheless, there are theoretical reasons for caution in the use of inhaled NO treatment. The formation of hydroxyl radicals might cause oxidative damage to tissue. ${ }^{14} \mathrm{NO}$ might impair energy metabolism ${ }^{57}$ or promote inflammation, ${ }^{28}$ and it has been suggested that $\mathrm{NO}$ is involved in mediating the effects of pertussis toxin in airways. ${ }^{58}$ DNA damage in Salmonella species due to NO has been recorded, and as cigarette smoke contains NO this has been proposed as one mechanism for the carcinogenic effect of smoking. ${ }^{5960}$ Some evidence of deteriorations in lung function during inhalation of $\mathrm{NO}$ has been produced in studies of adult volunteers: a mean fall in arterial oxygen tension of $7 \mathrm{~mm} \mathrm{Hg}$ was recorded in 191 normal subjects inhaling NO of $15-20 \mathrm{ppm}$, and at higher concentrations airways resistance increased. ${ }^{16}$

\section{Conclusion}

$\mathrm{NO}$ is a multifunctional biological mediator with clear pharmacological effects when inhaled into the lung. Considerable gaps remain in our understanding of the pharmacology and toxicology of this novel inhalational treatment, and enthusiasm for NO treatment should be tempered with caution.

I thank Professor $\mathbf{M}$ Hughe and Miss $\mathbf{S}$ Khan for their invaluable advice.

1 Furchgott RF, Zawadski JV. The obligatory role of endothelial cells in the relaxation of arterial smooth muscle by acetylcholine. Nature 1980; 288: 373-6.

2 Palmer RM, Ferrige AG, Moncada S. Nitric oxide release accounts for the biological activity of endothelium-derived relaxing factor. Nature 1987; 327: 524-6.

3 Palmer RM, Ashton DS, Moncada S. Vascular endothelia cells synthesize nitric oxide from L-arginine. Nature 1988 333: 664-6. 
4 Rees DD, Palmer RMJ, Schulz R, Hodson HF, Moncada S. Characterisation of three inhibitors of endothelial nitric oxide synthase in vitro and in vivo. Br f Pharmacol 1990 101: 746-52.

5 Moncada S, Palmer RMJ, Higgs EA. Nitric oxide: Physiology, pathophysiology and pharmacology. Pharmacol Rev 1991; 43: 109-42.

6 Takei Y, Edwards AD, Lorek A, Peebles DM, Belai A, Cope M, et al. Effects of Nitro-L-Arginine methyl ester on the cerebral circulation of newborn piglets quantified in vivo by near infrared spectroscopy. Pediatr Res 1993; 34: 354-9.

7 Dawson TM, Dawson VL, Snyder SH. A novel neuronal messenger molecule in the brain: the free radical, nitric messenger molecule in the brain: the

8 Green SJ, Nacy CA, Meltzer MS. Cytokine-induced synthesis of nitrogen oxides in macrophages: a protective host response to Leishmania and other intracellula pathogens. f Leuk Biol 1991; 50: 93-103.

9 Anggard E. Nitric oxide: mediator, murderer, and medicine. Lancet 1994; 343: 1199-206.

10 Bonner FT, Steadman G. The chemistry of nitric oxide and redox-related species. In: Stamler J, Feelish $\mathbf{M}$, eds. Methods in nitric oxide research. Chichester: John Wiley, (in press).

11 Stamler JS, Singel DJ, Loscalzo J. Biochemistry of nitric oxide and its redox-activated forms. Science 1992; 258: 1898-902.

12 Lipton SA, Choi YB, Pan ZH, Lei SZ, Chen HS, Sucher $\mathrm{NJ}$, et al. A redox-based mechanism for the neuroprotective and neurodestructive effects of nitric oxide and tive and neurodestructive effects of nitric oxide and
related nitroso-compounds. Nature 1993; 364: 626-32.

13 Beckman JS, Beckman TW, Chen J, Marshall PA, Freeman BA. Apparent hydroxyl radical production by peroxynitrite: implications for endothelial injury from nitric oxide and superoxide. Proc Natl Acad Sci USA 1990; 87 1620-4

14 Radi R, Beckman JS, Buch KM, Freeman BA. Peroxynitrite oxidation of sulfhydryls. The cytotoxic potential of superoxide and nitric oxide. F Biol Chem 1991; 266: 4244-50.

15 Foubert L, Fleming B, Latimer R, Jonas M, Oduro A, Borland C, et al. Safety guidelines for use of nitric oxide. Lancet 1992; 339: 1615-6.

16 Gaston B, Drazen JM, Loscalzo J, Stamler JS. The biology of nitrogen oxides in the airways. Am Rev Respir Dis 1994 149: $538-51$.

17 Centers for Disease Control. Recommendations for occupational safety and health standards. MMWR 1988; 37 (suppl): 21 .

18 Keaney JFJ, Simon DI, Stamler JS, Jaraki O, Scharfstein J, Vita JA, et al. NO forms an adduct with serum albumin that has endothelium-derived relaxing factor-like properties. F Clin Invest 1993; 91: 1582-9.

19 Higenbottam $T$. Inhaled nitric oxide: a magic bullet? $Q \mathcal{F}$ Med 1993; 86: 555-8

20 Moncada S. The 1991 Ulf von Euler Lecture. The L-arginine: nitric oxide pathway. Acta Physiol Scand 1992; 145. 201-7.

21 Stamler JS, Jaraki O, Osborne J, Simon DI, Keaney J, Vita $\mathrm{J}$, et al. Nitric oxide circulates in mammalian plasma primarily as an S-nitroso adduct of serum albumin. Proc Nat Acad Sci USA 1992; 89: 7674-7.

22 Roberts JDJ, Lang P, Bigatello LM, Vlahakes GJ, Zapo WM. Inhaled nitric oxide in congenital heart disease. Circulation 1993; 87: 447-53.

23 Kinsella JP, Abman SH. Methaemoglobin during nitric oxide therapy with high-frequency ventilation. Lancet 1993; 342: 615.

24 Gruetter CA, Gruetter DY, Lyon JE, Kadowitz PJ, Ignarro LJ. Relationship between cyclic guanosine $3^{\prime}: 5^{\prime}$ monophosphate formation and relaxation of coronary arterial smooth muscle by glyceryl trinitrate, nitroprusside, nitrite and nitric oxide: effects of methylene blue and side, nitrite and nitric oxide: effects of methylene blue and

25 Wolin MS, Wook KS, Ignarro LJ. Guanylate cyclase from bovine lung. A kinetic analysis of the regulation of unpurified soluble enzyme by protoporphyrin IX, haem and nitrosyl-haem. F Biol Chem 1982; 257: 11312-20.

26 Bolotina VM, Najibi S, Palacino JJ, Pagano PJ, Cohen RA. Nitric oxide directly activates calcium-dependent potassium channels in vascular smooth muscle. Nature 1994 368: 850-3.

27 Lander HM, Sehajpal PK, Novogrodsky A. Nitric oxide signalling: a possible role for $\mathrm{G}$ proteins. $\mathcal{f}$ Immunol 1993; 151: 7182-7.

28 Salvemini D, Misko TP, Masferrer JL, Seibert K, Currie MG, Needleman P. Nitric oxide activates cyclooxygenase MG, Needleman P. Nitric oxide activates cyclooxyge

29 Feelisch M, te Poel M, Zamora R, Deussen A, Moncada S. Understanding the controversy over the identity of EDRF. Nature 1994; 368: 62-5.

30 Mathews WR, Kerr SW. Biological activity of S-nitrosothiols: the role of nitric oxide. $\mathcal{f}$ Pharmacol Exp Ther 1993; 267: 1529-37.

31 Hogman M, Frostell C, Arnberg H, Hedenstierna G Bleeding time prolongation and $\mathrm{NO}$ inhalation. Lancet 1993; 341: 1664-5.

32 Groll-Knapp E, Haider M, Kienzl K, Handler A, Trimme $M$. Changes in discrimination learning and brain activity due to combined exposure to $\mathrm{NO}$ and $\mathrm{CO}$ in rats. Toxicol 1988; 49: 441-7.

33 Barnes PJ. Nitric oxide and airways. Eur Respir f 1993; 6 : 163-5.

34 Zapol WM, Falke KJ, Hurford WE, Roberts JDJ. Inhaling nitric oxide: a selective pulmonary vasodilator and bronchodilator. Chest 1994; 105: 87-91S.

35 Nelin LD, Moshin J, Thomas CJ, Sasidharan P, Dawson CA. The effect of inhaled nitric oxide on the pulmonary circulation of the neonatal pig. Pediatr Res 1994; 35: 20-4.

36 Etches PC, Finer NN, Barrington KJ, Graham AJ, Chan WK. Nitric oxide reverses acute hypoxic pulmonary hyper-

the newborn piglet. $P$ Us Use of inhaled nitric oxide and acetylcholine in the evaluation of pulmonary hypertension and endothelial function after cardio

38 Welte M, Zwissler B, Habazettl H, Messmer K. PGI aerosol versus nitric oxide for selective pulmonary vasodilation in hypoxic pulmonary vasoconstriction. Eur Surg Res 1993; 25: 329-40.

39 Berger JI, Gibson RL, Redding GJ, Standaert TA, Clarke WR, Truog WE. Effect of inhaled nitric oxide during group B streptococcal sepsis in piglets. Am Rev Respir Dis 1993; 147: 1080-6.

40 Gerlach H, Pappert D, Lewandowski K, Rossaint R, Falke $\mathrm{KJ}$. Long-term inhalation with evaluated low doses of nitric oxide for selective improvement of oxygenation in patients with adult respiratory distress syndrome. Intensive Care Med 1993; 19: 443-9.

41 Kurose I, Wolf R, Grisham MB, Granger DN. Modulation of ischemia/reperfusion-induced microvascular dysfunction by nitric oxide. Circ Res 1994; 74: 376-82.

42 Dembinska Kiec A, Zmuda A, Wenhrynowicz O, Stachura J, Peskar BA, Gryglewski RJ. Selectin-P-mediated adherence of platelets to neutrophils is regulated by prostanoids and nitric oxide. Int $\mathcal{F}$ Tissue React 1993; 15: 55-64.

43 Tod ML, Cassin S. Endothelin-1-induced pulmonary arterial dilation is reduced by $N$ omega-nitro-L-arginine in fetal lambs. F Appl Physiol 1992; 72: 1730-4.

44 Kourembanas $S$, McQuillan LP, Leung GK, Faller DV. Nitric oxide regulates the expression of vasoconstrictors and growth factor by vascular endothelium under both and growth factor by vascular endothelium under both

45 Buga GM, Griscavage JM, Rogers NE, Ignarro LJ. Negative feedback regulation of endothelial cell function by nitric oxide. Circ Res 1993; 73: 808-12.

46 Rengasamy A, Johns RA. Regulation of nitric oxide synthase by nitric oxide. Mol Pharmacol 1993; 44: 124-8.

47 Assreuy J, Cunha FQ, Liew FY, Moncada S. Feedback inhibition of nitric oxide synthase activity by nitric oxide. Br F Pharmacol 1993; 108: 833-7.

48 Finkel MS, Oddis CV, Jacob TD, Watkins SC, Hattler BG, Simmons RL. Negative inotropic effects of cytokines on the heart mediated by nitric oxide. Science 1992; 257: 387-9.

49 Lowenstein CJ, Dinerman JL, Snyder SH. Nitric oxide: physiologic messenger. Ann Intern Med 1994; 120 227-37.

50 Pantopoulos K, Weiss G, Hentze MW. Nitric oxide and post-transcriptional control of cellular traffic. Trends Cell Biol 1994; 4: 82.

51 Mulligan MS, Hevel JM, Marletta MA, Ward PA. Tissue injury caused by deposition of immune complexes is $\mathrm{L}$ arginine dependant. Proc Natl Acad Sci USA 1991; 88, 6338-42.

52 Ialenti A, Moncada S, Di Rosa M. Modulation of adjuvan arthiritis by endogenous nitric oxide. $\mathrm{Br} \mathcal{f}$ Pharmacol 1993; 110: 701-6.

53 Moncada S, Higgs A. The L-arginine-nitric oxide pathway. N Engl F Med 1993; 329: 2002-12.

54 Dalkara T, Moskowitz MA. The complex role of nitric oxide in the pathophysiology of focal cerebral ischaemia Brain Pathol 1994; 4: 49-57.

55 Stavert DM, Lehnert BE. Nitric oxide and nitrogen dioxide as inducers of acute pulmonary injury when inhaled at relatively high concentrations for brief periods. Inhalational Toxicol 1990; 2: 53-67.

56 Oriot D, Boussemart T, Berthier M, Bonneau D, Coisne D. Paradoxical effect of inhaled nitric oxide in a newbor with pulmonary hypertension. Lancet 1993; 342: 364-5.

57 Cleeter MW, Cooper JM, Darley-Usmar VM, Moncada S Schapira AVH. Reversible inhibition of cytochrome c oxidase, the terminal enzyme of the mitochondiral respiratory chain, by nitric oxide. FEBS Lett 1994; 345: p0-4.

58 Heiss LN, Lancaster JRJ, Corbett JA, Goldman WE. Epithelial autotoxicity of nitric oxide: role in the respiratory 1994; 91: 267-70.

59 Nguyen T, Brunson D, Crespi CL, Penman BW, Wishnok JS, Tannenbaum SR. DNA damage and mutation in human cells exposed to nitric oxide in vitro. Proc Nat Acad Sci USA 1992; 89: 3030-4.

60 Routledge MN, Wink DA, Keefer LK, Dipple A. Mutation induced by saturated aqueous nitric oxide in the pSP189 supF gene in human Ad293 and E coli MBM7070 cells. Carcinogenesis 1993; 14: 1251-4. 